\title{
Article
}

\section{Free to succeed: Does press freedom influence the entrepreneurial orientation and the reader revenue performance of independent news media firms?-A cross- sectional study}

Nel, Francois Pierre, Milburn-Curtis, Coral, Lehtisaari, Katja and Kammer, Aske

Available at http://clok.uclan.ac.uk/35979/

Nel, Francois Pierre ORCID: 0000-0003-4378-9171, Milburn-Curtis, Coral, Lehtisaari, Katja and Kammer, Aske (2020) Free to succeed: Does press freedom influence the entrepreneurial orientation and the reader revenue performance of independent news media firms?-A cross-sectional study. Newspaper Research Journal, 41 (4). pp. 417-432. ISSN 0739-5329

It is advisable to refer to the publisher's version if you intend to cite from the work. http://dx.doi.org/10.1177/0739532920969918

For more information about UCLan's research in this area go to http://www.uclan.ac.uk/researchgroups/ and search for <name of research Group>.

For information about Research generally at UCLan please go to http://www.uclan.ac.uk/research/

All outputs in CLoK are protected by Intellectual Property Rights law, including Copyright law. Copyright, IPR and Moral Rights for the works on this site are retained by the individual authors and/or other copyright owners. Terms and conditions for use of this material are defined in the policies page. 


\title{
AUTHOR ACCEPTED MANUSCRIPT
}

Citation:

Nel, F., Milburn-Curtis, C., Lehtisaari, K. and Kammer (2020, forthcoming). Free to Succeed: Does press freedom influence the entrepreneurial orientation and the reader revenue performance of independent news media firms? A cross-sectional study. Newspaper Research Journal, Autumn 2020, pp. xxx. At: https://journals.sagepub.com/home/nri

\section{FREE TO SUCCEED: Does press freedom influence the entrepreneurial orientation and the reader revenue performance of independent news media firms? A cross-sectional study.}

François Nel // Coral Milburn-Curtis // Katja Lehtisaari // Aske Kammer

\begin{abstract}
Here the notion of Entrepreneurial Orientation (EO) is operationalized to explore the influence of press freedom (PF) on the performance of news media firms. We find that growth in reader revenues $(R R)$ - digital and print - is statistically significantly correlated to both EO and PF, suggesting that subscriptions to independently produced news are likely to be better in countries with high degrees of press freedom, and in instances where the firm's leaders are entrepreneurial.
\end{abstract}

Keywords: Management/Economics/Personnel; Business/Management/Personnel; Press and Society; Gov't-Press Relations /Public Policy; Law 


\section{Introduction}

It is no secret that the sustainability of the independent press is of wide concern as firms worldwide face threats to their finances and their freedoms.

The double-sided business model on which the industry has long depended has not translated well into the digital realm (Nel, 2010). On the one side, many publishers have been able to grow audiences, but on the other, they have not necessarily been able to grow revenues - as competition for advertising income by local and global actors both within and beyond the news sector has intensified. This has spurred a pivot to reader revenues and a rise in what the latest World Press Trends report from WANIFRA, the World Association of Newspapers', describes at the 'the subscription economy' (Nel \& Milburn-Curtis, 2019, p. 7). At the same time, press freedom advocates, such as Freedom House and Reporters Without Borders, have sounded alarms about declines in press freedom worldwide from America to Zimbabwe. In parallel, the distinct but related phenomena of innovation and entrepreneurship have moved center-stage in the news media industry (Khajeheian, 2017). In academic circles too, it is argued that "journalism is enjoying its entrepreneurial moment" (Cohen, 2015, p.515).

Perhaps it is not surprising that entrepreneurship has been of increased interest to media scholars and others concerned about the future of independent news and the sustainability of the organizations that produce it (Achtenhagen, 2008; Hoag, 2008; Khajeheian, 2017). After all, entrepreneurship is widely accepted as a critical part of economic development and growth and considered important for the continued dynamism of the modern economy (World Bank 2002; Oksana, Mole, Lockett, Hayton, Ucbasaran \& Hodgkinson, 2015). However, that has not always been top of mind in our sector. In fact, as Compaine and Hoag (2012, p.30) argue, "entrepreneurship of any sort is not a concept that has been closely identified with the media industry". Yet, scholars such as Hoag (2008) and Vos \& Singer (2016) maintain that the industry has been more 
entrepreneurial in recent times than other manufacturing enterprises in the United States and other Western democracies. Even so, in the decade after Achtenhagen (2008) observed that "the area of media entrepreneurship is still a young and undeveloped field, this phenomenon is poorly understood" (2008, p. 124), it had been noted that "no significant progress can be seen" (Khajeheian, 2017, p. 92). As a result, "the field is not clear enough yet, and there is no consensus among the experts of the field" (Khajeheian, 2017, p.92). That summary is perhaps unduly harsh given contributions by, for example, Hang (2016) and Hass (2016) (alongside those by Khajeheian himself), but it is clear that the lack of consensus on the character of media entrepreneurship can still impede research and has made it especially difficult to investigate the relationship between media entrepreneurship and performance.

Nonetheless, progress is being made. More recently, Hang (2020) reported on comprehensive bibliometric analysis of media and entrepreneurship and concluded that the period since 2017 has been a boon for studies in this area as scholars have embraced the challenge to fill in the gaps of both theory and empirical data. For example, Horst \& Murchetz (2019) theorized the intersection of entrepreneurship and strategy to offer a foundation for studies into the process of the strategic media entrepreneurship pathway that aims at organizational success. Organizational success and entrepreneurialism in news media firms is further scrutinized by Nel, Milburn-Curtis \& Lehitsaari (2020) in their analysis of data drawn from 107 countries. Their findings show that, in times of significant volatility, entrepreneurial news media firms which prioritize the exploration of new opportunities are significantly more likely to reap financial rewards than their counterparts that focus most of their energies on exploiting existing markets; however, they worry about the limitations on such entrepreneurialism wrought by the political economic contexts in which news media firms operate. The relevance of such concerns is underlined by scholars like Shreekala (2020), who identifies that digital news media entrepreneurship in India is constrained by government and corporate controls. 
Thus number of questions remain, including: What are the linkages amongst entrepreneurialism, organizational performance and political-economic constraints? This study addresses that issue by specifically considering two matters of wide concern inside and outside industry circles - the financial sustainability of independent news media firms and the declines in press freedom - in combination with a perspective that Achtenhagen (2020) recently noted is mostly absent from our field: the concept of Entrepreneurial Orientation.

\section{Review of key concepts}

\section{Entrepreneurial Orientation (EO) as indicator of organizational innovativeness}

Though widely explored in the general business literature over more than two decades since it was conceptualized, the notion of Entrepreneurial Orientation (EO) has not often surfaced in media management scholarship (Achtenhagen 2020). Pioneered by Lumpkin and Dess (1996), EO is characterized by a readiness to innovate and take risks, a bent to be aggressive toward competitors and a proactiveness relative to marketplace opportunities (p.137). Such factors may be present when a firm engages opportunistically. However, organizations may also successfully exploit opportunities when only some of these aspects are at work. That is, the degree to which each of these elements is useful in predicting the nature and success of an entrepreneurial endeavor may be subject to external dynamics like the business environment (Lumpkin \& Dess, 1996) and the nature of the industry, or by internal actors, such as the organizational culture (in the case of an existing firm) or the characteristics of the founders (in the case of startups). Thus, EO has the potential to lead to improved firm performance (Wiklund and Shepherd, 2005). Miller (2011, p. 880) has argued that, "the components of EO are more telling than the aggregate index". While encouraging more research to examine the effects of single EO dimensions on the overall EO, Miller (2011) observes that "in some research contexts, the best of both worlds may entail analyses that present results for the EO construct and for each of its components" (p. 880). The concern of the present study is not whether either 
perspective is more correct than the other since, as Covin and Miller (2014) note, both are legitimate.

Entrepreneurialism in the media has been investigated at many different levels, for example, individuals (Compaine \& Hoag, 2012), teams (Page West, 2007), organizations (Usher, 2017), and even ecosystems (Powers and Vera-Zambrano, 2017). We here take it that the essential opportunistic act of entrepreneurship primarily occurs at the level of the organization or firm, which Lumpkin and Dess (1996) point out is considered as a "non-diversified economic unit" (p.139). Thus, entrepreneurship may be initiated by an individual, a small firm, or the strategic unit of a large conglomerate. As such, this study of EO will focus on the firm/business-unit level. This firm-level approach is consonant with classical economics that regards the individual entrepreneur as a firm, whether or not they have followed legal protocols (Lumpkin \& Dess, 1996).

Reader Revenue $(R R)$ as an indicator of organizational performance

We recognize that for media firms, amongst others, value is not only considered in economic terms (Picard, 2010). We are convinced by argument of Rao \& Weintraub (2013) who posit that the value of a successful innovations can be captured at three levels: external, enterprise and personal. We are also alert to the case Bøe-Lillegraven (2014) makes for the potential that Big Data offers to assess the performance of news organizations by offering insights into, amongst others, the productivity of individual staff members and specific pieces of content alongside traditional financial measures.

However, in this paper we focus our attention on an indicator of performance that is of particular contemporary interest: subscription revenues. That is because subscriptions indicate both editorial value and economic value as the offers meet readers' quality expectations enough for them to take money out of their pockets to pay for it. Furthermore, it could be argued that subscription growth might also imply EO because to exploit marketplace opportunities by cultivating, in particular, digital subscriptions (or 'paywalls') publishers need to innovate and take risks. 
These insights helped shape the Reader Revenues (RR) variable employed in this study, which is a combination of both changes in print subscriptions and in digital subscriptions.

Press Freedom (PF) as indicator of market environment

Just like all other organizations, news media firms exist in relation to other actors and within frameworks of institutions, etc. (Mintzberg, 1979). The conditions under which they operate are formed by the environment within which they exist, and their navigation of this environment determines how they engage in relation to other actors. It is important to remember that news media companies are "not just any other business" (McQuail, 2010, p.190) because they ideally also serve social and democratic ends, rather than just commercial ones. Indeed, as pointed out in the World Press Trends report (Nel \& Milburn-Curtis, 2019a) and elsewhere (Milburn-Curtis \& $\mathrm{Nel}, 2019 \mathrm{~b}$ ), it is becoming increasingly clear that press freedom is inextricably linked with a range of political, economic and social factors that themselves underpin the sustainability of the media.

Important contexts for news media firms are the media systems and political structures in which they are embedded. Media systems are "typical patterns of how journalism culture, media policy, media markets, and media use are connected in a given society" (Brüggemann, Engesser, Büchel, Humprecht, \& Castro, 2014, p.1038). Broadening this perspective, Cohen (2015, p.514) notes that, "the vision of the journalist as entrepreneur takes up contemporary society's entrenched fixation on the entrepreneur as a remedy for broader political, economic, and social problems and signals a shift for an industry and practice that until recent decades had been dominated by large, somewhat stable media corporations with large, if volatile, ranks of employees". To this end, one might add that the social and historic characteristics of the environment that the news media exist within play a role in forming how they operate. Scholars have, for example, traced the extensive Scandinavian frameworks for media subsidies back to the Social-Democratic welfare state that these societies epitomize (Kammer, 
2016; Syvertsen, Enli, Mjøs and Moe, 2014), and studies of political communication illustrate how systemic differences reflect upon journalistic production (Humprecht and Esser, 2018). More recently, calls for increased state subsidies have grown stronger on the back of concerns about disruptive forces challenging the press worldwide (Murschetz 2020, Picard 2019). Their discussions also underline the importance of press ownership. In our study, we focus on independent press, by which we mean commercial and non-profit news media firms that are neither directly or indirectly owned and controlled government or politicians

What else might be true, this much we do know: without press freedom there is little space for either the independent, critical journalism or the negotiation of public opinion that constitute foundational pillars in liberal democracies (Schudson, 2008). Tellingly, a free press is not only widely considered a necessary condition for well-functioning democracies but also for well-functioning economies. Indeed, in the foreword to a seminal collection of studies by the Nobel Prize-winning economist Joseph Stiglitz and others published by the World Bank (2002), the head of the World Bank's Poverty Reduction and Economic Management Unit Roumeen Islam notes, "a free press is not a luxury. It is a core of equitable development" (p. v).

It is suggested that a free press, protected by the rule of law, supports a robust, competitive and effective media (SCMP, 2019). Whilst "economic freedom and press freedom are closely intertwined" (Kim \& Tyrell, 2018, p.1), debate continues regarding the direction of causality between the two, and the basic assumption has not been extensively tested empirically. We therefore focus our lens on an exploration of the relationship between press freedom (PF), entrepreneurial orientation (EO) and the reader revenues $(\mathrm{RR})$ of media organizations.

In doing so we recognize the complex relationship between media freedom and overall economic performance, as vividly illustrated by the cases of the United States and China which are the world's largest and second largest economies, respectively (World Bank 2019), whilst being ranked 45th and 176th, out of 180 on the 2019 Press 
Freedom Index (https://rsf.org/en/ranking). In addition, China has since 1946 been a member of UNESCO, which sees cultivating media pluralism and independence as an extension of its core mandate "to foster 'the unrestricted pursuit of objective truth', 'the free exchange of ideas and knowledge' and 'the free flow of ideas by word and image', as prescribed by UNESCO's Constitution" (Mendel, 2008, p.1). Founding member, the United States, in its turn, withdrew from UNESCO on 1st January 2019.

\section{Research Questions}

On the basis of these theoretical positions and empirical findings, we explore whether the performance of independent news media firms - in particular with reference to their reader revenue performance (RR) and indeed entrepreneurial orientation (EO) itself is related to press freedom (PF).

Specifically, we ask, 'to what extent is press freedom related to the financial performance of news media firms and their entrepreneurial orientation?' by exploring the following sub-questions:

- RQ1: What is the relationship between RR and EO?

- RQ2: What is the relationship between PF and EO?

- RQ3: What is the relationship between RR and PF?

\section{Materials and Methods}


The study used data collected from 246 respondents in 69 countries $^{1}$ These comprised: $64 \%$ from 'developed' countries; $36 \%$ from 'developing' countries; Europe: 50\%; Americas: 21\%; East \& South Asia: 14\%; Middle East \& Africa: 15\%. Data were collected via a 2016 survey, in association with the World Association of Newspapers and News Publishers (WAN-IFRA). Data were taken from one year of an ongoing annual global survey of senior news media executives. These were top managers $(43 \%)$, editorial managers $(30 \%)$, commercial and technology managers $(23 \%)$, as well as academics and researchers (4\%). Participating organizations were privately owned (32\%), public service (46\%), not-for-profit (4\%) and cooperatives (6\%). Government owned organizations (12\%) were excluded from this analysis, as our approach involved exploring only independent press organizations. Therefore the final sample consisted of 214 participants from 62 countries (see Appendix 1).

The 22-question online survey collected data about country, language, world region, national income, area of work, size of organization, circulation, revenues and profitability, ownership, geographic focus, publishing and non-media activity, and 12 month and 5-year investment priorities. Organizational behavior was captured with Likert scale items which explored entrepreneurial and innovation orientation, attitudes to change, organizational values, behaviors, management climate, investment in people, processes and perceived success. Participants were asked to respond on a scale of 1 (total disagreement) to 7 (total agreement), to statements such as those detailed in Table 1.

These online questionnaires were offered in Arabic, Chinese, English, Finnish, French, German, Italian, Japanese, Persian, Portuguese, Russian, and Spanish, and participants could choose which language to use. Confidentiality was assured to participants in the consent document, and personal details, if they were supplied, were separated from the survey results before analysis. Email addresses, if supplied, were kept separately and used if participants requested information about study outcomes.

\footnotetext{
${ }^{1}$ See Appendix 1
} 
Using a purposive sampling strategy, our sampling frame included as much of the available population of managers of news media organizations, in national, regional and local media. This strategy is appropriate where the population has a particular set of characteristics which are not very common, and where the population is relatively small (Black, 2012). In order to address the limitations of this strategy, we only aimed to make analytical generalizations, rather than statistical ones. Thus, findings are related to the research questions derived through theory, and care has been taken not to generalize to a larger population.

It was not our intention to attribute causal conclusions. However, we were nevertheless able to address issues around our principal research problem which was to explore the strength of relationships between indicators of press freedom, financial performance and entrepreneurial orientation.

\section{Measures}

We focused on two key variables from our annual survey data (EO and RR) and one constructed from other global indices (PF).

\section{Entrepreneurial Orientation}

Entrepreneurial Orientation, is a normally distributed continuous variable, created from an aggregate of six items. It measures attitudes to risk, proactiveness and competitive aggression (Lumpkin and Dess, 1996) and is measured by asking for responses on an agreement scale of 1 to 7 , as detailed in Table 1 . The scale was subject to confirmatory factor analysis, using maximum likelihood estimation. This confirmed the a priori structure of the scale, with a unidimensional factor which explained $63 \%$ of the variance. All factor loadings were significant and greater than .42. The Kaiser-MeyerOlkin measure of sampling adequacy (Kaiser, 1974) indicated that, at 0.821, the sample size was appropriate for factor analysis, and the Cronbach's Alpha, a measure of reliability (Cronbach, 1951) was .82.

[insert Table 1] 


\section{Reader Revenues}

Reader Revenue (RR) is a normally distributed continuous variable, measuring change in subscriptions revenues over the 12 months preceding the study year. Participants were asked to report on the extent to which, over the previous year, their print and website revenues had increased or decreased. We combine print and digital reader revenue since news publishers worldwide (e.g. New York Times, US, and The Times, UK) offer bundled subscriptions and because news publisher associations (e.g. Newsworks UK) have strongly argued for reporting a single reader revenue metric across all formats, print and digital (DeGroose, 2019). The two manifest 7-point scales were thus aggregated into one variable, the descriptives for which can be found in Table 2.

\section{Press Freedom}

We considered two normally distributed continuous measures of press freedom: Freedom House ${ }^{[1]}$ and Reporters Without Borders ${ }^{[2]}$ (RWB). Freedom House publishes yearly reports on freedom of the press that gives each of 199 countries and territories a score from 0 to 100 . The level of press freedom is evaluated through 23 questions divided into categories covering the legal environment, the political environment, and the economic environment. Reporters Without Borders determines the degree of freedom available to journalists by using the responses of experts to a questionnaire. Their Press Freedom Index is a publicly available dataset, which presents press freedom scores for 180 countries. The index is made up of two elements. The first details the results of a survey which explores 'pluralism, media independence, media environment and self-censorship, legislative framework, transparency, and the quality of the infrastructure that supports the production of news and information'. The second 
publishes quantitative data on abuses and acts of violence against journalists during the period evaluated.

Since, at the time of this study, there was a high correlation between the two press freedom indices (>.9), we took the mean of the two as our press freedom variable. The resulting variable was normally distributed: (Skewness $=.913$; Kurtosis $=.086$ ).

\section{Results}

We express correlations in terms of Pearson's $r$ correlation coefficient, with a significance cut-off of $p<.05$, i.e., there is less than a $5 \%$ probability that our results could have been achieved by chance. All variables of interest conformed to the assumptions required for correlational analysis (continuous data; normal distribution; no significant outliers; linear relationships).

Correlational analysis revealed significant relationships across all three of our variables of interest (see Table 3).

[Insert Table 3]

Finding RQ1: There was a positive and statistically significant correlation between Reader Revenues and Entrepreneurial Orientation $(r=.18 ; p<.05)$.

Finding RQ2: Press Freedom was also significantly related to Entrepreneurial Orientation $(r=.15 ; p<.05)$.

Finding RQ3: Press Freedom was significantly related to Reader Revenues ( $r=.22 ; p$ $<.01)$. 


\section{Summary of findings}

The study finds that financial performance of independent news media organizations (in terms of reader revenues) is statistically and significantly correlated with two factors, namely 1) press freedom and 2) the entrepreneurial orientation of the firm, with all reported results having at least a $95 \%$ probability of not having been achieved by chance.

That suggests that, in our sample, news publishers exhibit better overall performances in countries with high degrees of press freedom and in instances where the firm's culture is oriented towards being entrepreneurial.

\section{Discussion}

Worldwide, news operations have been redesigned, revamped, reorganized, converged (Siapera and Vergelis, 2012) and de-converged (Tameling and Broersma, 2013). Websites have been launched and relaunched. A wide array of mobile and tablet apps offer consumers news that might be variously aggregated, expanded, editioned, condensed, interactive, pushed, augmented or experienced in 3D. And although many companies have been able to grow audiences, they have often struggled to grow revenues. The once-Golden Rule of multisided markets that "money follows eyeballs" rarely materialized (Nel, Lehtisaari and Milburn-Curtis, 2017). As such, the future of quality journalism and the news media organizations that principally supply it continues to worry industry insiders, consumers, policy makers and academics worldwide (Wahl-Jorgensen, Williams, Sambrook, Harris, Garcia-Blanco, Dencik, Cushion, Carter \& Allan, 2016). Thus it is not surprising that there has been heightened interest in the one thing that has widely been recognized to spur technological progress, business expansion and wealth creation for both start-up ventures and existing firms: entrepreneurship (Ahmad and Hoffman, 2007). 
Of late, the focus of news media entrepreneurialism has increasingly shifted towards generating reader revenues, principally through subscriptions to print and digital products. In doing so, news publishers worldwide have recognized that they have broadly lost their once-firm grip on the flow of advertising and, often reluctantly, have embraced the logic Rupert Murdoch first articulated in 2009 when he said, "There's not enough ad revenue in the world to make all the websites profitable. We'd rather have fewer people coming to our websites but paying" (Speers 2009). Labelled as 'paywalls', subscription models have not worked out for all who tried, but there have been successes in all markets, at a range of levels of press freedom. Zimbabwe, for example, with a population of around 14 million ranks amongst the world's poorest nations with Gross National Income of just US\$1790 per capita in 2018, while it was ranked $126^{\text {th }}$ amongst the 180 nations and regions monitored by Reports Without Borders. Even so, that year Zimbabwe's Daily News and Financial Gazette put up a hard paywall on all online news platforms, including mobile sites, and saw digital subscribers' numbers climbing to nearly 80,000 , according to publisher Jethro Goko (Nel \& Milburn-Curtis, 2019). This is a remarkably strong performance when compared with the 27,000 digital subscribers of the New York Daily News and the 72,000 digital subscribers of The Dallas Morning News in the America, whose population of 372 million in 2018 had a GNI per capita of $\$ 63,200$ while it ranked $45^{\text {th }}$ on RWB's press freedom index (lbid).

This change in online revenue strategy has brought about a focus on user quality expectations, which should be welcomed by those who are worried about the rise of "click-bait as a strategy that seeks to lure users into clicking on a link to a page through tactics such as sensationalist stories and eye-catching headlines that work as bait" (Bazaco et al, 2019, p.1). However, the shift towards quality expectations of users is not only evident in editorial activities as the emphasis turns from attention-seeking approaches, which drive the traffic volumes that are the key metric for advertisingbased strategies, to engagement-seeking endeavors, which are essential for the retention of subscribers (Newman, 2020). The changes in activities and performance 
metrics necessitates a profound paradigm shift from a product-oriented mindset, to a services mindset (Nel \& Milburn, 2017). That is, a shift from an emphasis on information products (stories), to an emphasis on information engagement and utility (service).

Whatever else, this turn has highlighted the need to re-examine some assumptions about a variety of interrelated issues to build our understanding about how news media firms' successes or failures are related to external market forces - and to internal choices made by their leaders.

Here we have underlined the relationship between entrepreneurial orientation and a measure of organizational performance. This study finds that growth in reader revenues of independent news publishers in our sample has more to do with the EO of their organizations than with the general differences and dynamics found in both advanced and developing economies. This suggests that entrepreneurially oriented leaders have significant agency in the success of their firms and can make the choices that help their companies flourish whatever the typical market conditions. However, we also find that restrictions in press freedom are likely to negatively correlate with the reader revenue performance of these news media firms. Thus, these findings are likely to bolster the cause of those working to ensure independent, pluralistic press systems that have enabling legislative framework and quality infrastructures, and environments where journalists are able to access and use information with high degrees of autonomy free from abuses, acts of violence and official constraints.

\section{Summary, limitations and directions for future research}

This study tests some basic assumptions about the extent to which the performance of news media firms are related to, on the one hand, the firm's EO and, on the other hand, to the wider media environment. In doing so, it has contributed analytically, theoretically, and empirically to the study of media management and economics, by: 
a) determining that there was a statistically significant relationship between financial performance of firms in our study and its EO.

b) identifying that country level Press Freedom and organizational level EO were significantly correlated.

c) identifying that country level Press Freedom and organizational level Reader Revenues were significantly correlated.

\section{Limitations}

While the results are based on a large sample, it should be noted that these findings are limited to a self-selected sample of media managers and their self-reported measures, and are not necessarily generalizable to a wider population. Research questions have been addressed through the objective analysis of quantitative data, and care has been taken not to generalize to a larger population (i.e., including those potential participants, who for one reason or another chose not to participate). As participants were self-selected, they therefore potentially possessed characteristics which we were not able to measure (for instance, the most stressed managers may not have had time to complete the survey). Furthermore, the contact method (email) may have resultant limitations for participation.

Implications for the industry

These findings raise questions that further underline the concerns of those who see press freedoms under threat from the anti-press rhetoric of world leaders like President Donald Trump, during whose presidency the United States has dropped to 48th in the latest RWB press freedom index (RSF, 2019). Trump's antagonism to the press is argued to echo beyond the U.S. borders, giving rise to what is popularly referred to as the 'Trump Effect' (Frank, 2018). Thus, the decline in press freedom in the world's largest economy would necessarily concern all those who care that press are free to 
succeed editorially and economically. This study identifies that the greater an organization's EO, in terms of their innovativeness, approaches to risk, pro-activeness, competitive aggression and autonomy, the greater the reader revenues. The significant relationship between press freedom in the country and the financial performance of the firm, suggests that the freedom of the press should be of concern to editorial and commercial leaders alike.

\section{Directions for Future Research}

This study contributes to the theoretical understanding of how systems of governance (including press freedom) represent fertile or hostile environments for media performance and it broadens the scope of comparative research to a world-wide setting, beyond the Western-centric perspective that is usually prevalent (see, e.g., Hallin and Mancini, 2012). Furthermore, the limitations stated above are guiding us towards potential new openings. For the research on hand, we limited ourselves to looking at the connections between press freedom, EO and company's reader revenue performance in the sample. However, there are questions that arise from the data, including those concerning different sub-groups in the study. Are there other geographical differences, or differences between media manager generations?

Furthermore, we are mindful that, as Lumpkin and Dess (1996, p. 153) point out "in investigating the entrepreneurial orientation-performance relationship, it is essential to recognize the multidimensional nature of the performance construct"(see also Chakravarthy, 1986). As such, there is an opportunity to investigate the entrepreneurial orientation-performance relationship with reference not only to other aspects of financial performance, such as growth and market share, but also broader external dimensions, such as journalistic reputation and social impact, and internal dimensions, such as satisfaction and commitment of staff (c.f. Nel, Milburn-Curtis and Lehtisaari, 2020). 
Certainly this is an issue that warrants further attention in future research which, like this study, responds to Picard and Lowe's (2016, p. 63) appeal for ambitious media management scholarship that does "not simply describe cases, highlight issues and challenges and documents perspectives and behaviors," but tests, expands and develops theory directly pertinent to media management sciences - and which will potentially be relevant to other fields too.

\section{Acknowledgement}

This study draws on primary data from an annual study by François Nel and Coral Milburn-Curtis that underpins the World News Publishers Outlook report and for WANIFRA, the World Association of Newspapers and News Publishers, without whose support a global study of senior news media decision makers would be very difficult to do.

\section{References}

Achtenhagen, L. (2020). Entrepreneurial orientation - an overlooked theoretical concept for studying media firms. Nordic Journal of Media Management, 1(1), 7-21. https://doi.org/10.5278/njmm.2597-0445.3668

Achtenhagen, L. (2008). Understanding Entrepreneurship in Traditional Media. Journal of Media Business Studies, 5(1),123-142.

Ahmad, N., \& Hoffman, A. (2007). A Framework for Addressing and Measuring Entrepreneurship. Entrepreneurship. Paris: OECD. 
Bazaco, A., Redondo, M., Sánchez-García, P. (2019): Clickbait as a strategy of viral journalism: conceptualisation and methods. Revista Latina de Comunicación Social, 74, pp. 94 to 115. DOI: 10.4185/RLCS-2018-1323en

Baird, I. S., \& Thomas, H. (1985). Toward a contingency model of strategic risk taking. Academy of Management Review, 10(2),230-243.

Black, Thomas R. (2012). Doing quantitative research in the social sciences. London, England: Sage.

Brüggemann, M., Engesser, S., Büchel, F., Humprecht, E., \& Castro, L. (2014). Hallin and Mancini Revisited: Four Empirical Types of Western Media Systems. Journal of Communication, 64(6),1037-1065.

Chakravarthy, B. S. (1986). Measuring strategic performance. Strategic management journal, 7(5),437-458.

Cohen, N. S. (2015). Entrepreneurial journalism and the precarious state of media work. South Atlantic Quarterly, 114(3),513-533.

Compaine, B., \& Hoag, A. (2012). Factors Supporting and Hindering New Entry in Media Markets: A Study of Media Entrepreneurs. International Journal on Media Management, 14(1),27-49.

Covin, J.G. \& Miller, D. (2014). International entrepreneurial orientation: Conceptual considerations, research themes, measurement issues, and future research directions. Entrepreneurship Theory and Practice, 38(1),11-44.

Cronbach, L.J. (1951). Coefficient alpha and the internal structure of tests. Psychometrika, 16, 297 - 334. 
DeGroose, T. (2019). The Missing Ten Billion. Speech: Society of Editors $20^{\text {th }}$ Anniversary Conference, London, 13/11/2019. Retrieved from:

https://www.newsworks.org.uk/news-and-opinion/society-of-editors-conference-themissing-billion?+

Domingo, D., Masip, P., \& Costera Meijer, I. (2014). Tracing digital news networks:

Towards an integrated framework of the dynamics of news production, circulation and use. Digital Journalism, 3(1),53-67.

Ferrier, M. B. (2013). Media entrepreneurship: Curriculum development and faculty perceptions of what students should know. Journalism \& Mass Communication Educator, 68(3),222-241.

Frank, J. (2018). Speechless: The Trump Effect. The New Yorker. Retrieved from https://www.newyorker.com/news/daily-comment/speechless-the-trump-effect.

Hallin, D. C., \& Mancini, P. (2012). Comparing media systems: A response to critics. Handbook of comparative communication research, 207-220.

Hoag, A. (2008). Measuring media entrepreneurship. The International Journal on Media Management, 10(2),74-80.

Horst, S. O., \& Murschetz, P. C. (2019). Strategic media entrepreneurship: Theory development and problematization. Journal of Media Management and Entrepreneurship (JMME), 1(1), 1-26.

Humprecht, E., \& Esser, F. (2018). Diversity in Online News. On the importance of ownership types and media system types. Journalism Studies, 19(12),1825-1847.

Hunter, A., \& Nel, F. P. (2011). Equipping the entrepreneurial journalist: An exercise in creative enterprise. Journalism \& Mass Communication Educator, 66(1),9-24. 
Kaiser, H.F. (1974). An index of factorial simplicity. Psychometrika, 39, 31 - 36.

Kammer, A. (2016). A welfare perspective on Nordic media subsidies. Journal of Media Business Studies, 13(3),140-152.

Khajeheian, D. (2017). Media entrepreneurship: a consensual definition. AD-minister, [S.I.], n.30, p.91-113, feb.2017.

Kim, A.B. \& Tyrell, P. (2018). Why a Free Press Is Actually Good for the Economy. The Heritage Foundation, Retrieved on 21.10.19 from:

https://www.heritage.org/international-economies/commentary/why-free-press-actuallygood-the-economy

Küng, L. (2015). Innovators in Digital News. London: I.B. Tauris.

Küng, L. (2017a). Going Digital: a roadmap for organisational transformation. Oxford: Reuters.

Küng, L. (2017b). Strategic Management in the Media: theory to practice. 2nd ed. London: Sage.

Lee, T. B. (2016). Print newspapers are dying faster than you think. Vox. Retrieved from https://www.vox.com/new-money/2016/11/2/13499004/print-newspapers-dying.

Lumpkin, G. T., \& Dess, G. G. (1996). Clarifying the entrepreneurial orientation construct and linking it to performance. Academy of Management Review, 21(1),135172.

Media Press Freedom Index. (2019). Available at: https://rsf.org/en/ranking table 
Mendel, T. (2008). Applying UNESCO's Media Development Indicators: A Practical Guidebook to Assist Researchers. UNESCO.

Milburn-Curtis, C.J. \& Nel, F.P. (2019). Measuring, Monitoring, Mapping and Modelling a Sustainable Global Media Ecosystem: a pilot study. Paper presented at IAMCR 2019 conference in Madrid, Spain, July 7-11, 2019.

Miller, D. (1983). The correlates of entrepreneurship in three types of firms. Management science, 29(7),770-791.

Miller, D. (2011). Miller (1983) revisited: A reflection on EO research and some suggestions for the future. Entrepreneurship Theory and Practice, 35(5),873-894.

Murschetz, P. C. (2020). State Aid for Independent News Journalism in the Public Interest? A Critical Debate of Government Funding Models and Principles, the Market Failure Paradigm, and Policy Efficacy. Digital Journalism, 1-20.

Nel, F. (2010). 'Where else is the money? A study of innovation in online business models at newspapers in Britain's 66 cities.' Journalism Practice, 4(3),360-372.

Nel, F.P. \& Milburn-Curtis, C.J. (2019). World Press Trends 2019. Frankfurt: WANIFRA, the World Association of News Publishers.

Nel, F., Milburn-Curtis, C. \& Lehtisaari, K. (forthcoming) Choosing for Success: How Divergent Priorities of Innovating Leaders at Ambidextrous News Media Firms Reflect on the Bottom Line. Baltic Journal of Management, Special edition: Media Entrepreneurship in Emerging Markets (forthcoming).

Nel, F.P, Lehtisaari, K. \& Milburn-Curtis, C.(2015). Exploring confidence: entrepreneurial leadership in news media organisations. International Media 
Management Academic Association (IMMAA) Annual Conference. p. 170-174. ISSN 978-5-19-010987-0.

Nel, F.P, Lehtisaari, K. \& Milburn-Curtis, C. (2017). Entrepreneurial leadership and the performance of news media firms. Future of Journalism Conference 2017, 14-15 September, Cardiff, UK.

Oksana, K., Mole, K. F., Lockett, A., Hayton, J. C., Ucbasaran, D., \& Hodgkinson, G. P. (2015). Entrepreneurial leadership, capabilities and firm growth. International Small Business Journal, 33(1),89-105.

Page West, G. (2007). Collective Cognition: When Entrepreneurial Teams, Not Individuals, Make Decisions. Entrepreneurship Theory \& Practice, 33(1).

Picard, R. G., \& Lowe, G. F. (2016). Questioning media management scholarship: four parables about how to better develop the field. Journal of Media Business Studies, 13(2),61-72.

Victor Pickard (2020) Restructuring Democratic Infrastructures: A Policy Approach to the Journalism Crisis, Digital Journalism, DOI: $\underline{10.1080 / 21670811.2020 .1733433}$

Powers, M., \& Vera-Zambrano, S. (2017). How journalists use social media in France and the United States: Analyzing technology use across journalistic fields. New Media \& Society.

Reporters Without Borders (2019). World Press Freedom Index. Online: https://rsf.org/en/ranking.

Schudson, M. (2008). Why Democracies Need an Unlovable Press. Cambridge: Polity Press. 
SCMP (2019). Media freedom is even more important in the world of today. South China Morning Post. Retrieved on 21.10.19 from: https://www.scmp.com/comment/insightopinion/article/3008629/media-freedom-even-more-important-world-today.

Siapera, E., \& Veglis, A. (2012, Eds.). The Handbook of Global Online Journalism. West Sussex: Wiley-Blackwell Publishing.

Speers, D. (2009). The Interview with David Speers, Sky News Australiam, 9 November 2009. Online: https://youtu.be/M7GkJqRv3BI

Syvertsen, T., Enli, G., Mjøs, O. J., \& Moe, H. (2014). The Media Welfare State. Nordic Media in the Digital Era. Ann Arbor: The University of Michigan Press.

Tameling, K., \& Broersma, M. (2013). De-converging the newsroom: Strategies for newsroom change and their influence on journalism practice. International Communication Gazette, 75(1),19-34.

Usher, N. (2017). Venture-backed News Startups and the Field of Journalism: Challenges, changes, and consistencies. Digital Journalism, 5(9),1116-1133.

Vos, T. P., \& Singer, J. B. (2016). Media discourse about entrepreneurial journalism: Implications for journalistic capital. Journalism Practice, 10(2),143-159.

Wahl-Jorgensen, K, Williams, A, Sambrook, R, Harris, J, Garcia-Blanco, I, Dencik, L, Cushion, S, Carter, C \& Allan, S (2016). The future of journalism: risks, threats and opportunities. Journalism Studies. 17(7),801-807.

Wiklund, J., \& Shepherd, D. (2005). Entrepreneurial orientation and small business performance: a configurational approach. Journal of business venturing, 20(1),71-91. 
World Bank, (2002). The Right To Tell: The Role of Mass Media in Economic

Development. Washington: WBI Development Studies.

World Bank (2019). https://data.worldbank.org.

[1] Methodology:https://freedomhouse.org/report/freedom-

press-2017-methodology.

${ }^{[2]}$ Methodology:https://rsf.org/en/detailed-methodology.

Appendix 1: Geographical distribution of participants: Afghanistan; Algeria; Argentina; Australia; Austria; Belgium; Bolivia; Brazil; Bulgaria; Canada; China; Colombia; Costa Rica; Czech Republic; Denmark; Ecuador; Egypt; El Salvador; Finland; France; Germany; Ghana; Greece; India; Indonesia; Iran; Ireland; Israel; Italy; Japan; Kenya; Latvia; Liberia; Luxembourg; Macau; Malaysia; Malta; Mexico; Namibia; Netherlands; Nigeria; North Macedonia; Norway; Pakistan; Philippines; Poland; Portugal; Romania; Russia; Singapore; South Africa; Spain; Sri Lanka; Sweden; Switzerland; Turkey; Uganda; Ukraine; United Arab Emirates; United Kingdom; United States; Zimbabwe.

Table 1: Dimensions of Entrepreneurial Orientation and survey questions

\begin{tabular}{|l|l|}
\hline $\begin{array}{l}\text { Dimensions of entrepreneurial } \\
\text { orientation }\end{array}$ & Indicator / questions \\
\hline $\begin{array}{l}\text { Innovativeness reflects a "firm's tendency to } \\
\text { engage in and support new ideas, novelty, } \\
\text { experimentation, and creative processes } \\
\text { that may result in new products, services, or } \\
\text { technological processes" (Dess \& }\end{array}$ & - We have a deliberate, comprehensive \\
\end{tabular}




\begin{tabular}{|c|c|}
\hline $\begin{array}{l}\text { Lumpkin, 1996: 142). Kimberly (1981) } \\
\text { states that innovativeness represents a } \\
\text { basic willingness to depart from existing } \\
\text { technologies or practices and venture } \\
\text { beyond the current state of the art (Lumpkin } \\
\text { \& Dess, 1996). Rauch et al. (2009: } 273 \text { ) } \\
\text { describe innovativeness as the } \\
\text { "predisposition to engage in creativity and } \\
\text { experimentation through the introduction of } \\
\text { new products/services as well as } \\
\text { technological leadership via R\&D in new } \\
\text { processes". }\end{array}$ & \\
\hline $\begin{array}{l}\text { Risk, taken here to be indicated by the } \\
\text { willingness to venture into the unknown (c.f. } \\
\text { Baird and Thomas, 1985). }\end{array}$ & $\begin{array}{l}\text { We have a burning desire to explore } \\
\text { opportunities and to use our resources to } \\
\text { create new things. }\end{array}$ \\
\hline $\begin{array}{l}\text { Proactiveness, taken here to be indicated to } \\
\text { act in anticipation of future problems, needs } \\
\text { or changes in line with the definition in } \\
\text { Webster' Ninth New Collegiate Dictionary } \\
(1991, \text { p.937). }\end{array}$ & $\begin{array}{l}\text { - There is an urgency felt throughout the } \\
\text { organization that our business needs to } \\
\text { change. } \\
\text { We are constantly looking for new ways to } \\
\text { make money beyond traditional sources } \\
\text { (i.e. subscriptions, advertising). }\end{array}$ \\
\hline $\begin{array}{l}\text { Competitive aggression, taken here to } \\
\text { challenge competitors and the status quo. }\end{array}$ & $\begin{array}{l}\text { - In dealing with competitors, my firm is very } \\
\text { often the first business to introduce new } \\
\text { products, services, administrative } \\
\text { techniques, operating technologies, etc. }\end{array}$ \\
\hline
\end{tabular}


Autonomy means having the ability and motivation to self-direct the pursuit of opportunity. Specifically applied to an organizational context, autonomy is action taken free from organizational constraints (Lumpkin \& Dess, 1996). Rauch et al. (2009: 764) explain autonomy as "independent action undertaken by entrepreneurial leaders or teams directed at bringing about a new venture and seeing it to fruition".
- Our company's culture encourages everyone to be innovative.

\begin{tabular}{|l|c|l|l|l|l|}
\hline Table 2: Descriptives & \multicolumn{1}{|c|}{ SD } & Skewness & Kurtosis \\
\hline Entrepreneurial Orientation & 199 & 4.8 & 1.16 & -.29 & -.25 \\
\hline Reader Revenues & 214 & 8.1 & 1.65 & .28 & .29 \\
\hline Press Freedom & 214 & 32.4 & 18.56 & .91 & .09 \\
\hline
\end{tabular}

Table 3: Correlational analysis of variables of interest

\begin{tabular}{|c|c|c|c|}
\hline $\begin{array}{c}\text { Correlations: } \\
\text { Pearson's } r\end{array}$ & EO & PF & RR \\
\hline EO & & $r=.15 ; p<.05$ & $r=.18 ; p<.05$ \\
\hline PF & $r=.15 ; p<.05$ & & $r=.22 ; p<.01$ \\
\hline RR & $r=.18 ; p<.05$ & $r=.22 ; p<.01$ & \\
\hline
\end{tabular}

EO: Entrepreneurial Orientation; PF: Press Freedom; RR: Reader Revenues 
- END- 